\title{
Neutrophil and Lymphocyte (N/L) Ratio of Gestation and Lactation Sapera Goats at Kambing Farm, Sukoharjo, Ngaglik, Sleman
}

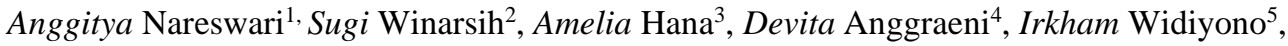 \\ and Sarmin $^{3 *}$. \\ ${ }^{1}$ Faculty of Veterinary Medicine, Universitas Gadjah Mada, Yogyakarta, Indonesia \\ ${ }^{2}$ Food Agriculture and Fisheries Office of Sleman, DIY \\ ${ }^{3}$ Departement of Physiology, Faculty of Veterinary Medicine, Universitas Gadjah Mada \\ ${ }^{4}$ Departement Surgery, Faculty of Veterinary Medicine, Universitas Gadjah Mada \\ ${ }^{5}$ Departement Internal Medicine, Faculty of Veterinary Medicine, Universitas Gadjah Mada
}

\begin{abstract}
Neutrophil to lymphocyte ratio is used to analyse stress levels before the method of measuring glucocorticoid levels in blood plasma exists. The study aims to determine the neutrophil to lymphocyte (N/L) ratio in Sapera goats during a clinically normal gestation and lactation period. The samples were obtained from 12 Sapera goats in three-month gestation period and 12 Sapera goats in three-month lactation period. Blood samples taken via jugular veins were used as the preparation of blood smears to calculate the neutrophil to lymphocyte ratio. The average calculation result of the N/L ratio in the lactation group $(0.47 \pm 0.23)$ was higher $(\mathrm{p}<0.05)$ than the gestation group $(0.19 \pm 0.12)$ with a positive moderate correlation $(r=0.59)$. The conclusion of this study indicates that while being in the normal range, the N/L ratio in Sapera goats during lactation period was higher than the ratio in Sapera goats during gestation period.
\end{abstract}

Keywords: Gestation, goat, lactation, ratio of N/L, sapera goat

\section{Introduction}

Goats are one of the potential livestock because they are easy to raise, are resistant to climate change, and breed throughout the year. Based on their purpose, goats are divided into three, namely meat goats, dairy goats and dual-purpose goats. One of the new dairy goats that are cultivated in Indonesia is Sapera. The Sapera goat is the result of cross-breeding between a Saanen Full Blood goat from Switzerland and a Peranakan Etawa (PE) goat from Indonesia $^{[10]}$.

During their life, female goats will experience several changes in physiological status, including the phases of puberty, pregnancy, and lactation. Pregnancy and lactation physiology can be a factor in changes in body metabolism which lead to changes in goats' hematology ${ }^{[7]}$, because the metabolic activity during gestation period will increase within

\footnotetext{
*Corresponding author: sarminkh76@ugm.ac.id
} 
the mitochondria of the placenta ${ }^{[3]}$ and $80 \%$ of the blood metabolism of lactating goats will be used to produce milk ${ }^{[11]}$.

Calculation of the neutrophils to lymphocytes (N/L) ratio is easier and more economical compared to cortisol measurement using Elisa method. However, research that employs N/L ratio calculation method has not been widely carried out on goats during gestation and lactation period, and there are no other references that study Sapera goats. Based on this background, this study focuses on calculating the N/L ratio in clinically healthy pregnant and lactating Sapera goats.

\section{Material and Methods}

All methods in this research have been approved by the ethics commission of the Integrated Research and Testing Laboratory of Universitas Gadjah Mada (Laboratorium Penelitian dan Pengujian Terpadu Universitas Gadjah Mada/LPPT UGM) number 00035/04/LPPT/VII/2019.

\subsection{Location and time of study}

The research was conducted at Kambing Farm, Kencuran Lor, Sukoharjo, Ngaglik, Sleman, DIY. Leucocyte staining and counting were carried out at the Physiology Laboratory, Faculty of Veterinary Medicine, UGM. This research was conducted in April - May 2019.

\subsection{Animals in the study}

This research studied 24 Sapera goats, consisting of 12 pregnant Sapera goats (gestation age of 3 months) and 12 lactating Sapera goats (3 months of lactation). The goats are kept in a cage with an area of $2 \times 3$ meters for 2 goats with an air temperature of $20 \mathrm{oC}$, humidity level of $49 \%$, and no direct exposure to sunlight. The floor of the cage is made of bamboo without litter and the roof was a gable roof made of wavy zinc board with a height of 4 meters. The goats were fed a mixture of mung beans, rice bran, and soybean husk in the morning and fresh forage in the afternoon.

The general examination of the goats included examination of the conjunctiva, gingiva of the mouth, respiratory rate, pulse frequency, and body temperature. Those examinations were carried out before the collection of blood samples. The examination showed that the goats did not show any symptoms of illness, so it was followed by the collection of blood samples.

\subsection{Haematology procedures}

Blood collection was carried out in the morning at 5:00 - 6.00 WIB before the goats were fed and milked. Handling and restraining of the goats were done manually to facilitate the process of blood collection. Blood was drawn through the jugular vein using a 5-cc syringe with a needle size of $21 \mathrm{G}$ (One Med PT. Jayamas Medica Industri, Sidoarjo). 70\% alcohol (OneMed PT. Jayamas Medica Industri, Sidoarjo) as an antiseptic was smeared using cotton pad on the area where the blood was drawn. Blood is collected in a vacuum tube containing EDTA (Ethylene Diamine Tetraacetic Acid) from PT. Jayamas Medica Industri, Sidoarjo to prevent blood coagulation until the leukocyte count was calculated.

Differential counting of leukocytes was carried out using a slide medium under a microscope. Blood was taken using a standard pipette and one drop of blood was placed on the end of the slide. Using another glass object at an angle of $45^{\circ}$, the drop of blood was touched and allowed to widen to the edge. Then, the drop was pushed along the first slide to form a thin 
blood smear and it was allowed to dry. After drying, the smear preparations were fixed using absolute methanol and allowed to dry. Then, the smear preparations were immersed in Giemsa solution diluted with distilled water at a ratio of 1:10 for 30 minutes. After that, the preparations were rinsed with water and $\operatorname{dried}^{[2]}$.The preparations were examined and each type of leukocytes was counted under a microscope using the straight edge method with weak magnification. Each type of leukocyte was calculated as a percentage, while the absolute value of each type of cell was obtained by multiplying it by the percentage of total leukocytes. Then, the absolute value of neutrophils and lymphocytes were compared to generate the N/L ratio according to Rajion method ${ }^{[8]}$.

\subsection{Statistical analysis}

The data from the examination of the N/L ratio were analyzed statistically using SPSS 16 application with the normality test and followed by the Mann-Whitney test. The test result was confirmed by the Pearson correlation test. The significance used in the analysis was $\mathrm{p}$ $<0.05$.

\section{Results and discussions}

The neutrophils to lymphocytes (N/L) ratio in the pregnant goat group was $0.19 \pm 0.12$ and the ratio in the lactating goat group was $0.47 \pm 0.23$. The $\mathrm{N} / \mathrm{L}$ ratio in each group of goats was still within normal limits. The peak of $\mathrm{N} / \mathrm{L}$ ratio in goats is $0.74 \pm 0.51^{[1]}$ and according to Rajion et al. the ratio level is $0.59 \pm 0.05^{[8]}$. While the $\mathrm{N} / \mathrm{L}$ ratio values of pregnant and lactating goats were still within the normal limit, statistical analysis using the Mann-Whitney test showed a significant difference in the $\mathrm{N} / \mathrm{L}$ ratio $(\mathrm{p}<0.05)$ between the group of pregnant goats and the group of lactating goats. Pearson correlation test for pregnant and lactating goat groups with the $\mathrm{N} / \mathrm{L}$ ratio showed a significant positive moderate correlation $(\mathrm{r}=0.59)$ (sig $<0.05)$. These results indicate that pregnancy and lactation have an effect on the N/L ratio in Sapera goats.

According to Palacios ${ }^{[7]}$ and Oliveira ${ }^{[6]}$, there are differences in the hematological and leukogram images between pregnant and lactating goats. Lymphocyte value will be higher in the gestation period, while the neutrophil value is higher in the lactation period ${ }^{[12,13]}$.

Table 1. N/L ratio in pregnant and lactating sapera goats

\begin{tabular}{lcc}
\hline Type of Goat & Average N/L Ratio & Reference \\
\hline Pregnant Sapera Goat (3 month) & $0.19 \pm 0.12^{\mathrm{a}}$ & $\begin{array}{c}0.59 \pm 0.05^{[8]} \\
0.74 \pm 0.51^{[1]}\end{array}$ \\
\hline Lactating Sapera Goat (3 month) & $0.47 \pm 0.23^{\mathrm{b}}$ & \\
\hline $\begin{array}{l}\text { Superscript letter (a.b) in the same column shows a significant difference }(\mathrm{P}<0.05) . \mathrm{N} / \mathrm{L}: \\
\text { Neutrophil/Lymphocyte }\end{array}$ & \\
\hline
\end{tabular}

The N/L ratio in lactating goats is higher because of mammogenesis, lactogenesis, and breastfeeding process during the lactation period. Estrogen and prolactin hormones that are produced in the lactation period can cause a high N/L ratio in lactating goats. Postpartum estrogen plays a role in mammogenesis and it can increase inflammation of the mammary gland which makes the neutrophil infiltration increases ${ }^{[4]}$. The N/L ratio is found to be higher in individuals with high level of prolactin hormone ${ }^{[5]}$.

Another factor that causes increased level of N/L in lactating goats is the milking. Unsatisfactory milking condition can be a stressor for the goats. The acute stress will 
stimulate the adrenal medulla to secrete catecholamines. The secretion of catecholamines will cause the neutrophil and lymphocyte values to increase. If the stressors occur for a long time, catecholamines will stimulate the hypothalamus to secrete Corticotropin Releasing Hormone $(\mathrm{CRH})$ which will stimulate the anterior pituitary to secrete the hormone adrenocorticotropin (ACTH). Adrenocorticotropin hormone will stimulate the release of cortisol which can lead to neutrophilia and lymphopenia ${ }^{[9]}$. Based on this process, the increased N/L ratio in lactating goats indicates that the stressors are chronic or they have occurred for a long time.

Pregnant goats tend to have a lower average N/L ratio compared to lactating goats because of progesterone hormone which is active during pregnancy. In addition to maintaining the pregnancy, progesterone can also stimulate the central nervous system to produce anti-stress so that the N/L ratio tends to be $\operatorname{low}^{[14]}$. The low N/L ratio is affected by the increased lymphocyte value. During the gestation perio,d the lymphocyte value will increase until the neonatal is born and the lymphoid organs are fully formed ${ }^{[12]}$.

\section{Conclusion}

Based on the results of this study, it can be concluded that the average neutrophil to lymphocyte (N/L) ratio in lactating Sapera goats is higher compared to pregnant Sapera goats even though the levels are still within the normal limits.

\section{Acknowledgments}

The authors would like to express their gratitude to Mr. Muslim for granting the permission and providing facilities in Kambing Farm to conduct this research.

\section{References}

1. Astuti, P., Sarmin, Kusumawati, A., Airin, C.M. Maheswari, H., Sjahfirdi, H. Comparison level of cortisol and ratio of neutrophil/lymphocytes as acute stress marker to long road trasnportation of bligon bucks. Yogyakarta: Seminar internasional penyakit tropikal dan zoonosis (2009)

2. Barger, A.M., Macneill, A.I. Clinical Pathology and Laboratory Techniques for veterinary technicians. India: Willey Blackwell (2015)

3. Bernardi, F., Guolo, F., Bortolin, T., Petronilho, F., Pizzol, F.D. Oxidative Stress and Inflammatory Markers in Normal pregnancy and Preeclampsia. Journal Compilation Japan Society of Obstetrics and Gynecology 34 (6) : 948 - 951 (2008)

4. Chung, H.H., Or, Y.Z., Shrestha, S., Loh, J.T., Lim, C.L., Ong, Z., Woo, A.R.E., Su, I., Lin, V.C.L. Estrogen reprograms the activity of neutrophils to foster protumoral microenvironment during mammary involution. Scientific Reports 7 (1) : 46485 (2017)

5. KebabÇilar, A., Ilhan, T.T., Ucar, M.G., Ipekci, S.H., Celik, C. Relationship between Prolactin Levels and Neurophil/Lymphocytes in Patients With Unexplained Infertility. Medical Journal of Aegean Clinics 53 (3) : 140 - 145 (2015)

6. Oliveira, W.D.C. Changes in Hematological Biomarkers of Nellore Cows at Different Reproductive Stage. Acta Scientarium., Animal Science 41. http://orcid.org/0000-00024786-1399 (2019)

7. Palacios, R.C., Fuente-Gomez, M.G., Ramirez-Orduna, J.M., Garcia-Alvarez, A., Llinascervantes, X., Angulo, C. Effects of pregnancy and post-kidding stages on 
haematochemical parameters in cross-bred goats. Journal of Applied Animal research 46 (1) : $269-273$ (2017)

8. Rajion, M.A., Saat, I.M., Idrus, Z., Goh, Y.M. The Effects of Road Transportation on Some Physiological Stress Measures in Goats. Journal of Animal Science 14 (9) : 1250 1252 (2001)

9. Satyaningtijas, A.S., Kusumorini, N., Purnomo, M.M.F. Profil Leukosit, Diferensial Leukosit, dan Indeks Stress Luwak Jawa (Paradoxurus hermaphroditus) [Leucocyte Profile, Differential Leucocyte, and Stress Index in Asian Palm Civets/Luwak Jawa (Paradoxurus hermaphroditus)]. Jurnal Veteriner 15 (4): 487 - 493 (2014).

10. Saputro, A.L., Hamid, I.S., Prasitya, R.A., Purnama, M.T.E. Hidroponik fodder jagung sebagai substitusi hijauan pakan ternak ditinjau dari produktivitas susu kambing sapera [A study of corn fodder hydroponics as a substitute for forage on milk productivity of sapera goat]. Jurnal medik veteriner 1 (2) : 48 - 51 (2018)

11. Salem, N.Y. Effect of Lactation on Haemato-Biochemical and Minerals Constituents in Small Ruminants. International Journal of Veterinary Science 6 (1) : 53 - 56 (2017)

12. Sharma, A., Kumar, P., Singh, M., Vasishta, N. K. Haemato-biochemical and endocrine profiling of north western Himalayan Gaddi Sheep during various physiological/ reproductive phases. Open Veterinary Journal 5 (2) : 103 - 107 (2015)

13. Simsek, O., Arikan, S., Cinar, M. Reference values for selected hematological and biochemical blood parameter from prepregnancy to advanced gestation in angora cats. Turkish Journal of Veterinary and Animal Science 39 (1) : 29 - 33 (2015)

14. Ungerfeld, R. and Freitas-de-melo, A. Stress and Behavioural Responses to Winter Shearing Differ Between Pregnant and Non Pregnant Ewes. Montevideo : Elsevier (2019) 